\title{
PENGARUH PARTISIPASI ANGGARAN, PERSEPSI KEADILAN DISTRIBUTIF, KEADILAN PROSEDURAL, DAN GOAL COMMITMENT TERHADAP KINERJA DINAS
}

\author{
I. G. K. Ulupui \\ Alumnus Magister Sains UGM
}

\begin{abstract}
This research examined the effects of budget participation on performance of offices on duty in Badung Regency. The offices turned out to be executive elements of local government directly involved in budget preparation and served as a working unit providing public services. Furthermore, the research looked for the effects of the distributive and procedural justice perception, and goal commitment on the performance. Samples taken in the research involved offices in Badung Regency. Unit analysis were the heads of the offices, since they were mostly involved in budget processing in the offices. Data were collected through questionnaires and interviews. Out of 87 questionnaires sent, only 79 could be processed in a regression method.

The results showed that budget participation had a significant effect on performance. This research also proved that justice perception, especially procedural justice, showed a positive and significant effect, while distributive justice perception showed an in-significant effect. It indicates that the higher justice perception, the higher performance of offices. On the other hand, the relationship between goal commitment and budget participation was negative and significant. It is not in line with the research of Wentzel (2002), and Locke \& Latham (1990), which said that individual's performance would be better when it had a commitment to reach special goals.
\end{abstract}

Keywords: budget participation, distributive justice, procedural justice, budget performance.

\section{PENDAHULUAN}

Hal-hal yang berkaitan dengan hubungan partisipasi anggaran dan kinerja telah diteliti secara luas, namun kebanyakan bukti-bukti empiris memberikan hasil yang bervariasi dan tidak konsisten, misalnya Kenis (1979), Brownell (1982), Brownell dan Mc.Innes (1986), Frucot dan Shearon (1991), dan Indriantoro (1995) menemukan bahwa partisipasi penganggaran dan kinerja memiliki hubungan yang sangat positif. Sedangkan peneliti lain seperti Sterdy (1960), Bryan dan Locke (1967), Chenhall dan Brownell (1988), dan Milani (1975) menemukan partisipasi penganggaran tidak meningkatkan kinerja.

Beberapa penelitian yang meneliti pengaruh partisipasi anggaran terhadap kinerja berusaha untuk mendamaikan konflik ini dengan mengadopsi pendekatan kontinjensi (Brownell, 1982; Govindarajan, 1986; Mia, 1989; Gul et al., 1995; Vincent dan Kar, 2000; dan Wentzel, 2002). Pendekatan kontinjensi menyebabkan adanya variabel-variabel lain yang bertindak sebagai variabel moderating atau variabel intervening (Brownell, 1982; Murray, 1990; Shields dan Shields, 1998).

Argyris (1964) dalam Mpaata dan Handoko (1998) memandang partisipasi terutama sebagai alat untuk mencapai tujuan (as a means to an end). Menurut mereka, partisipasi adalah alat untuk mengintegrasikan kebutuhan individu dan organisasi. 
Penelitian ini mencoba melakukan pengujian ulang mengenai pengaruh partisipasi anggaran serta persepsi tentang keadilan distributif, keadilan prosedural dan goal commitment terhadap kinerja. Variabel ini diuji secara terpisah untuk mengetahui variabel mana yang paling mempengaruhi kinerja. Selain itu penggunaan variabel ini juga dipengaruhi oleh pendapat bahwa penelitian dalam bidang penganggaran menyatakan persepsi tentang keadilan dapat berperan dalam kinerja (Wentzel, 2002). Persepsi keadilan yang dimaksud adalah keadilan distributif dan keadilan prosedural. Keadilan distributif yaitu keadilan hasil aktual yang diterima oleh pegawai (Gilliland, 1993) sedangkan menurut Magner dan Johnson (1995) keadilan distributif berkaitan dengan outcome karena penekanannya adalah pada distribusi yang diterima terlepas dari bagaimana distribusi tersebut ditentukan. Selanjutnya Magner dan Johnson menyatakan jika dikaitkan dengan penganggaran publik, keadilan distributif sesuai dengan pandangan fair share yaitu suatu konsep pembagian yang adil berkaitan dengan ukuran distribusi sumber daya yang harus diterima oleh satu unit kerja pemerintah dikaitkan dengan unit kerja yang lainnya. Sedangkan keadilan prosedural berkaitan dengan keadilan dalam prosedur-prosedur yang digunakan untuk menentukan distribusi hasil tersebut (Leventhal, 1980). Sementara itu variable goal commitment dipilih karena diharapkan dalam proses penyusunan anggaran, seseorang akan berusaha mencapai sasaran anggaran yang telah disepakati. Pengertian goal commitment menurut Kreitner dan Kinicki (2000), merupakan "sejumlah komitmen untuk mencapai sasaran" yakni seberapa luas seseorang memiliki komitmen pribadi untuk mencapai suatu sasaran. Artinya manajer yang memiliki tingkat goal commitment yang tinggi akan memiliki pandangan positif dan akan berusaha berbuat yang terbaik untuk mencapai sasaran tersebut.

Anggaran daerah merupakan alat dalam menentukan pendapatan dan pengeluaran, membantu pengambilan keputusan perencanaan pembangunan, otorisasi pengeluaran, sumber pengembangan ukuran-ukuran standar untuk penilaian kinerja, alat untuk memobilisasi pegawai dan alat koordinasi bagi semua kegiatan dari berbagai unit kerja. Unit-unit kerja pada pemerintah daerah seperti Dinas, merupakan unsur pelaksana pada pemerintah daerah.

Proses penyusunan anggaran pada pemerintah daerah merupakan tahapan yang cukup rumit dan melibatkan unit-unit kerja pemerintah seperti Dinas dan Instansi Teknis. Sistem desentralisasi yang diterapkan dalam kerangka otonomi daerah menyebabkan semakin luasnya tanggungjawab unsur-unsur pelaksana Pemda yaitu Dinas dalam hal penetapan kebijakankebijakan daerah. Salah satu bentuk perwujudan keterlibatan tersebut adalah partisipasi dalam penyusunan anggaran karena anggaran adalah perangkat atau alat manajemen dalam proses perencanaan dan pengawasan.

\section{TINJAUAN LITERATUR DAN PENGEMBANGAN HIPOTESIS 2.1. Partisipasi Penyusunan Anggaran dengan Kinerja}

Penemuan empiris yang berkaitan dengan hubungan langsung antara partisipasi anggaran dan kinerja memberikan hasil yang beragam. Beberapa penelitian yang menunjukkan hasil yang positif dan signifikan antara lain; Kenis (1979), melakukan penelitian terhadap 169 manajer departemen yang supervisor pabrik yang memiliki tanggung jawab terhadap anggaran yang berlokasi di New Jearsey-Philadelpia.Brownell (1982), melakukan studi lapangan terhadap 48 manajer pusat biaya tingkat menengah yang bekerja pada perusahaan manufaktur berukuran besar di San Fransisco.Brownell \& Mc.Innes (1986), melakukan penelitian dengan mengirimkan kuesioner kepada 224 manajer tingkat menengah dari berbagai fungsi pada tiga perusahaan manufaktur, dua perusahaan bergerak di bidang industri elektronik dan satu perusahaan bergerak di bidang industri baja. Mereka menemukan bahwa jika manajer diberikan partisipasi yang tinggi dalam penyusunan anggaran maka kinerjanya akan meningkat secara signifikan. Frucot dan Shearon (1991), melakukan penelitian terhadap warga negara Meksiko yang bekerja pada 21 perusahaan asing dan domestik yang terdiri dari 83 manajer. Indriantoro (1995), melakukan studi lapangan dengan mengirimkan kuesioner kepada 179 manajer dari berbagai fungsi seperti akun- 
tansi/keuangan, administrasi/personalia, produksi/operasi, sistem informasi dana pemasaran yang bekerja pada perusahaan-perusahaan yang berlokasi di Jakarta.

Penelitian mengenai partisipasi penyusunan anggaran pada pemerintah daerah pernah dilakukan oleh Indriani (1993), yang menguji pengaruh partisipasi anggaran terhadap prestasi kerja dan kepuasan kerja pada aparat pemerintah daerah tingkat II Propinsi Daerah Istimewa Aceh. Hasilnya menunjukkan ada hubungan yang signifikan antara partisipasi penyusunan anggaran dengan prestasi kerja. Fauziati (2002), yang meneliti pengaruh partisipasi penyusunan anggaran terhadap kepuasan kerja pegawai dan kinerja pemerintah Kabupaten dan Kota (Studi empiris pada Daerah Istimewa Yogyakarta). Hasilnya menunjukkan bukti bahwa partisipasi penyusunan anggaran berpengaruh terhadap kepuasan kerja dan tidak berpengaruh signifikan terhadap kinerja. Adoe (2002), menguji pengaruh karakteristik tujuan anggaran terhadap perilaku, sikap, dan kinerja aparat pemerintah daerah di Propinsi Nusa Tenggara Timur. Hasilnya menunjukkan partisipasi anggaran tidak berpengaruh terhadap kinerja.

Berdasarkan gambaran di atas hipotesis yang diajukan untuk melihat pengaruh partisipasi penyusunan anggaran dengan kinerja dinyatakan sebagai berikut:

H1. Partisipasi dalam penyusunan anggaran berpengaruh positif terhadap kinerja Dinas.

\subsection{Persepsi Keadilan Distributif, Keadilan Prosedural, dengan Kinerja}

Dua sisi keadilan yang dipertimbangkan dalam penelitian ini adalah keadilan distributif dan keadilan prosedural. Equity theory menyatakan teori keadilan distributif berhubungan dengan persepsi karyawan dan keseimbangan antara masukan-masukan (misalnya usaha yang dilakukan dan skill) yang mereka berikan dengan hasil-hasil (misalnya gaji) yang mereka terima. Pada saat individu-individu dalam organisasi mempersepsikan bahwa râsio masukan-masukan yang mereka berikan terhadap imbalan-imbalan yang mereka terima seimbang, mereka merasakan adanya kewajaran (equity). Di sisi lain, ketidak-seimbangan rasio antara masukan dan imbalan menggiring mereka pada persepsi akan adanya ketidak-wajaran (Cowherd dan Levine, 1992 dalam Pareke, 2000).

Penelitian ini cenderung menerima pandangan dari Magner dan Johnson (1995) yaitu konsep keadilan distributif berkaitan dengan pandangan "fair share"yang merupakan hal yang penting dalam literatur penganggaran publik. Suatu pembagian yang adil adalah harapan yang berkaitan dengan ukuran distribusi sumber daya yang harus diterima oleh satu unit kerja pemerintah dikaitkan dengan unit kerja yang lainnya (Magner dan Johnson, 1995).

Peran keadilan dalam proses penganggaran telah menjadi fokus riset akuntansi perilaku. Libby (1999) mengakui bahwa perusahaan yang bekerja dengan sumber-sumber yang terbatas tidak dapat memenuhi semua permintaan yang berkaitan dengan penganggaran. Artinya masalahmasalah tentang keadilan nampaknya akan muncul ketika Dinas menghadapi sumber-sumber daya yang terbatas.

Leventhal (1980) mengusulkan beberapa kriteria yang dapat digunakan dalam mengevaluasi keadilan dalam suatu proses pengalokasian: Respresentativeness: proses tersebut menggabungkan minat dan nilai-nilai dari semua subgroup penting dalam masyarakat yang dipengaruhi oleh keputusan itu; Accuracy: keputusan-keputusan yang berdasarkan informasi yang benar dan akurat, pendapat yang mengandung informasi yang baik; Competency: semua orang yang dipengaruhi oleh proses menerima perlakuan yang sama (konsistensi antar orang) dan proses yang digunakan dibuat dalam cara yang sama setiap saat (konsistensi antar waktu); Bias Suppression: pengambil keputusan tidak memiliki kepentingan pribadi dalam keputusan tersebut dan memberikan semua pandangannya dengan pertimbangan yang cukup; Correctability: proses tersebut memungkinkan melakukan koreksi terhadap keputusan yang buruk; dan Ethicality: proses tersebut sesuai dengan standar etika dan moralitas pribadi.

Penelitian sebelumnya berkenaan dengan persepsi keadilan dikaitkan dengan partisipasi dan kinerja adalah Libby (1999), memeriksa hubungan antara penggunaan proses penganggaran 
yang adil dan kinerja subordinat, yaitu pengaruh insentif terhadap proses penganggaran yang adil. Hasilnya menunjukkan bahwa proses penganggaran yang adil (kombinasi komponen voice dan explanation) memiliki pengaruh yang positif terhadap kinerja. Douthitt dan Aiello (2001), melakukan penelitian terhadap peran partisipasi dan pengendalian dalam pengaruh pemonitoran komputer terhadap persepsi keadilan, kepuasan tugas dan kinerja. Suatu studi laboratorium yang dimanipulasi dengan sampel 148 mahasiswa ini menyatakan partisipasi memiliki pengaruh yang positif terhadap persepsi keadilan prosedural. Wentzel (2002) meneliti pengaruh partisipasi anggaran terhadap persepsi keadilan manajer. Sampel yang digunakan adalah manajer pusat pertanggungjawaban yang terlibat dalam proses penganggaran. Hasilnya menunjukkan partisipasi dapat meningkatkan persepsi keadilan karena partisipasi memberikan kesempatan pada seseorang untuk mengekspresikan pandangannya sehingga memberikan konstribusi hubungan jangka panjang antara individu dengan kelompok yang pada akhirnya dapat meningkatkan kinerja. Libby (1999) menemukan bahwa kondisi keadilan prosedural yang tinggi meningkatkan kinerja subyek sedangkan Lindquist (1995) menemukan bahwa tidak ada pengaruhnya terhadap kinerja.

Berdasarkan hasil-hasil penelitian sebelumnya, maka untuk menguji pengaruh persepsi keadilan terhadap kinerja diajukan hipotesis sebagai berikut:

H.2. Keadilan distributif berpengaruh positif terhadap kinerja Dinas

H.3. Keadilan prosedural berpengaruh positif terhadap kinerja Dinas.

\subsection{Goal Commitment dengan Kinerja}

Goal commitment didefinisikan sebagai "Determinasi seseorang untuk mencapai sasaran" (Locke \& Latham, 1990). Goal commitment itu sendiri jika merujuk pada definisi yang dikemukakan oleh Hollenbeck dan Klein (1987) merupakan suatu kombinasi dari definisi-definisi yang dikemukakan sebelumnya oleh Locke, Shaw, Saari, dan Latham (1981) serta Campion dan Lord (1982) yaitu "menunjukkan luasnya usaha, sepanjang waktu (over time) ke arah pencapaian sasaran semula dan tidak adanya keinginan untuk membuang atau mengurangi sasaran" (Wright dan Kelly et al., 1994).

Berbagai studi menunjukkan kinerja individu lebih baik ketika mereka menerima dan memiliki komitmen untuk mencapai tujuan khusus (Locke \& Latham, 1990), karena manajer yang memiliki tingkat komitmen organisasi yang tinggi akan bersikap positif terhadap organisasinya yaitu ketika mereka mengidentifikasi diri mereka terhadap organisasi maka mereka akan mencoba untuk mempertahankan keanggotaannya dalam organisasi tersebut (Porter et al., 1976).

Penelitian-penelitian sebelumnya mengenai goal commitment dikaitkan dengan partisipasi dan kinerja antara lain dilakukan oleh Vincent dan Kar (2002) terhadap 79 manager tingkat menengah yang diambil secara acak pada perusahaan manufaktur di Australia menemukan adanya korelasi antara partisipasi anggaran dengan goal commitment. Wentzel (2002) dengan sampel manajer pusat pertanggungjawaban rumah sakit, menemukan bahwa goal commitment berpengaruh positif dan signifikan terhadap kinerja. Akibatnya, pengaruh partisipasi anggaran terhadap kinerja manajer bersifat tidak langsung dan tidak signifikan karena adanya pengaruh variabel pemediasi yaitu goal commitment.

Berdasarkan uraian di atas maka pengaruh goal commitment terhadap kinerja Dinas diuji dalam hipotesis berikut:

H.4. Komitmen Pimpinan Dinas terhadap sasaran anggaran (goal commitment) berpengaruh positif terhadap kinerja Dinas.

\section{METODA PENELITIAN}

\subsection{Pemilihan Sampel dan Metoda Pengumpulan Data}

Sampel yang akan diteliti adalah dinas yang ada di Kabupaten Badung. Unit analisis yang diteliti adalah Pimpinan Dinas_dalam hal ini mewakili Dinas-yang terdiri dari Kepala Dinas, 
Kabag TU dan Kasubdin. Data diperoleh dari responden melalui kuesioner dan wawancara pada Kepala Dinas dan juga pada Tim Anggaran Eksekutif serta Panitia Anggaran Legislatif.

\subsection{Pengukuran Variabel}

Terdapat lima variabel yang digunakan dalam penelitian ini dan diukur dengan instrumeninstrumen yang diambil dari instrumen Milani (1975), Magner dan Johnson (1995), Greenberg (1993), Wentzel (2002), Latham dan Steele (1983) dan satu variabel lainnya yaitu kinerja diambil dari hasil penelitian Adoe (2001) yang telah dimodifikasi oleh Mardiasmo (2001). Keenam variabel tersebut adalah:

Partisipasi anggaran: Partisipasi anggaran dalam penelitian ini merupakan variabel independen. Sesuai dengan definisi Milani (1975) partisipasi anggaran dalam penelitian ini ditentukan oleh tingkat keterlibatan dan pengaruh yang dirasakan oleh Pimpinan Dinas dalam proses perancangan anggaran.

Keadilan distributif: Keadilan distributif merupakan keadilan dalam pendistribusian anggaran yang diukur berdasarkan respon dari Pimpinan Dinas, dengan menggunakan lima item pertanyaan. Empat item diambil dari skala keadilan distributif Magner dan Johnson (1995). Satu item ditambahkan untuk menekankan segi interpersonal yang diperoleh dari skala keadilan distributif Greenberg (1993).

Keadilan prosedural: Keadilan prosedural merupakan sisi keadilan dalam penganggaran yang memperhatikan aspek prosedur yang digunakan dalam melakukan distribusi anggaran. Keadilan prosedural diukur berdasarkan respon yang diperoleh dari delapan pernyataan mengenai keadilan prosedural pada penelitian Magner and Johnson (1995) yang mengandung kriteria keadilan prosedural menurut Leventhal (1980).

Goal commitment: Goal commitment diukur menggunakan tiga item skala Latham dan Steele (1983) yang diadopsi oleh Wentzel (2002).

Kinerja: Kinerja merupakan prestasi yang diperlihatkan atau kemampuan kerja seseorang (Adoe, 2001). Kinerja yang diukur di sini mencakup kinerja pencapaian anggaran Dinas di Kabupaten Badung. Kinerja diukur dengan menggunakan tujuh pertanyaan yang terdiri dari satu pertanyaan berasal dari instrumen yang dikembangkan oleh Wentzel (2002) sedangkan enam item pertanyaan merupakan instrumen yang dikembangkan oleh Adoe (2001) yang telah dimodifikasi oleh Mardiasmo (2001).

Pengukuran variabel dengan menggunakan skala likert lima untuk semua pengukuran. Suatu pengukuran tunggal dibentuk dari setiap konstruk dengan merata-ratakan respon para Pimpinan Dinas untuk item-item pada setiap skala.

Alat yang digunakan untuk melihat pengaruh partisipasi anggaran, keadilan distributif, keadilan prosedural dan goal commitment terhadap kinerja adalah analisis dengan metoda regresi linier berganda. 


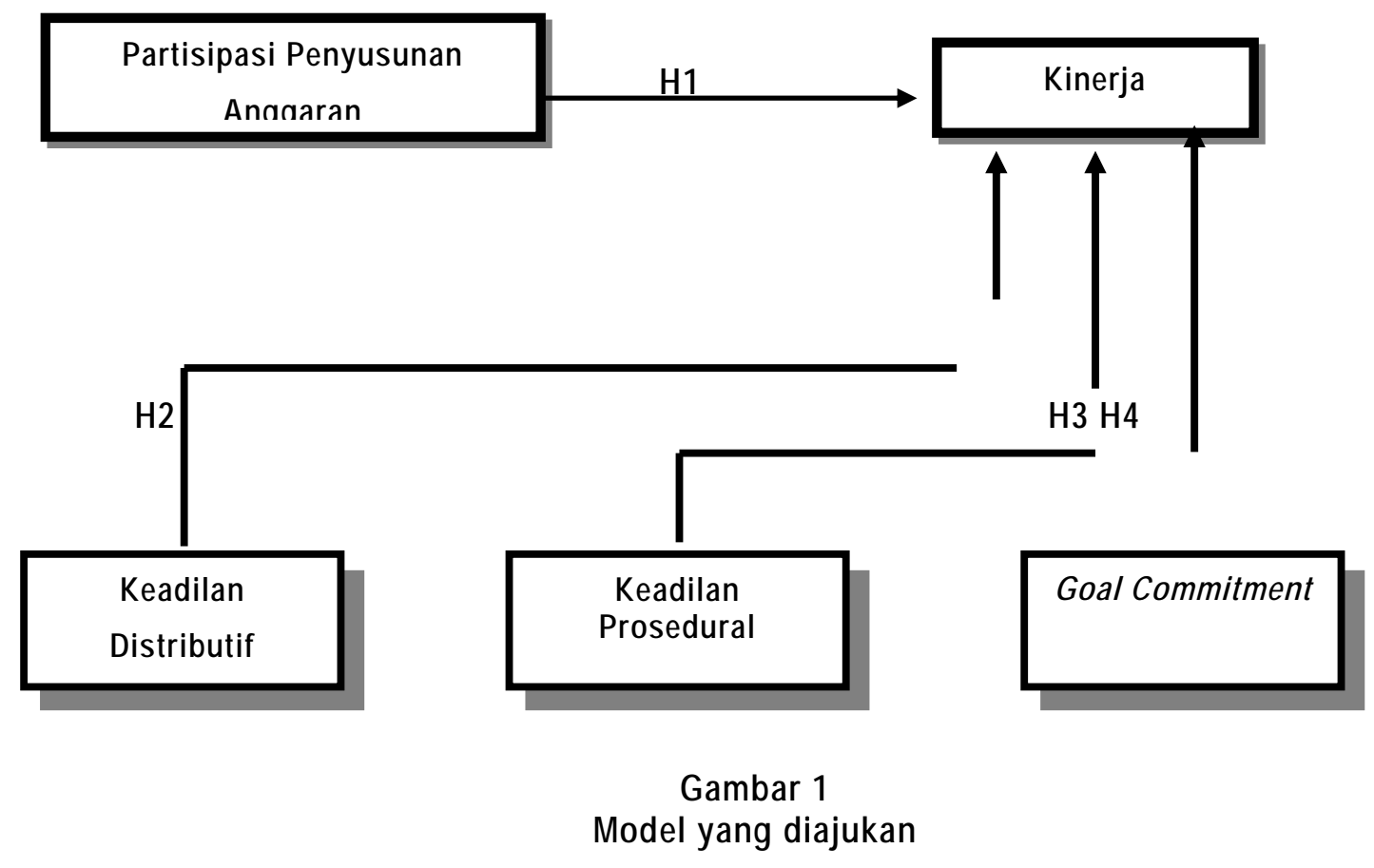

\section{ANALISIS DATA DAN PEMBAHASAN}

\subsection{Statistik Deskriptif}

Berdasarkan jawaban responden maka dapat disusun statistik deskriptif seperti yang nampak pada Tabel 2 berikut ini:

Tabel 2

Statistik Deskriptif

\begin{tabular}{llllll}
\hline Variabel & $\begin{array}{l}\text { Kisaran } \\
\text { Teoritis }\end{array}$ & $\begin{array}{l}\text { Kisaran } \\
\text { Aktual }\end{array}$ & Rata-rata & $\begin{array}{l}\text { Titik } \\
\text { tengah }\end{array}$ & $\begin{array}{l}\text { Deviasi } \\
\text { standar }\end{array}$ \\
\hline $\begin{array}{l}\text { Kinerja (Y) } \\
\text { Partisipasi (P) }\end{array}$ & $\begin{array}{l}7-35 \\
6-30\end{array}$ & $\begin{array}{l}7-35 \\
12-30\end{array}$ & 26,32 & 21 & 9,24 \\
$\begin{array}{l}\text { Keadilan } \\
\text { distributif (KD) }\end{array}$ & $5-25$ & $5-25$ & 13,91 & 18 & 4,99 \\
$\begin{array}{l}\text { Keadilan } \\
\text { Prosedural (KP) }\end{array}$ & $8-40$ & $8-40$ & 24,81 & 24 & 7,53 \\
$\begin{array}{l}\text { Komitmen } \\
\text { Terhadap sasaran (KO) }\end{array}$ & $3-15$ & $6-15$ & 12,46 & 9 & 2,04 \\
\hline
\end{tabular}

\subsection{Uji Validitas dan Reliabilitas}

Pengujian validitas instrumen dilakukan dengan cara seluruh item pertanyaan dianalisisfaktorkan dengan menggunakan software SPSS dan diuji dengan menggunakan metoda varimax rotation. Analisis faktor adalah analisis struktur hubungan (korelasi) diantara sejumlah variabel dengan menentukan suatu set dimensi yang disebut faktor. Chia (1995) mengatakan bahwa item-item yang terdapat dalam analisis faktor dengan factor loading lebih dari 0,40 adalah menunjukkan bahwa item pertanyaan tersebut valid. Selain itu suatu data dapat dinyatakan bisa 
dilakukan analisis faktor bila nilai Kaiser-Meyer-Olkin Measure of Sampling Adequacy (Kaiser's MSA) lebih besar dari 0,5 (Hair et al., 1998).

Uji reliabilitas dimaksudkan untuk mengetahui sejauh mana hasil pengukuran tetap konsisten, apabila dilakukan pengukuran dua kali atau lebih terhadap gejala yang sama. Penelitian ini mengganggap suatu instrumen reliable apabila hasil perhitungan Cronbach alpha lebih dari 0,60 (Nunnaly, 1994 dalam Ghozali, 2001). Hasil pengujian validitas dan reliabilitas instrumen dapat dilihat pada tabel berikut:

Tabel 3

Ringkasan Uji Reliabilitas dan Validitas

\begin{tabular}{llll}
\hline Variabel & $\begin{array}{l}\text { Cronbach } \\
\text { Alpha }\end{array}$ & Factor loading & $\begin{array}{l}\text { Kaiser's } \\
\text { MSA }\end{array}$ \\
\hline 1) Partisipasi & 0,9156 & $0,787-0,879$ & 0,866 \\
2) Keadilan distributive & 0,9409 & $0,839-0,934$ & 0,903 \\
3) Keadilan procedural & 0,9312 & $0,768-0,860$ & 0,900 \\
4) Goal Commitment & 0,8090 & $0,782-0,898$ & 0,671 \\
5) Kinerja & 0,9714 & $0,862-0,959$ & 0,882 \\
\hline
\end{tabular}

\subsection{Pengujian Hipotesis}

Teknik analisis yang digunakan untuk menguji hipotesis $1 ; 2 ; 3$ dan 4 yaitu regresi linier berganda. Langkah-langkah dalam proses analisa data seperti diuraikan berikut ini.

Hipotesis $\mathrm{H} 1, \mathrm{H} 2, \mathrm{H} 3$ dan $\mathrm{H} 4$ diuji dengan analisis regresi linier berganda untuk menguji apakah terdapat pengaruh partisipasi penyusunan anggaran $(P)$ Keadilan Distributif (KD), Keadilan Prosedural (KP), dan Goal commitment (KO) terhadap kinerja (Y). Hasil analisis yang diolah dengan menggunakan program Statistical Product and Service Solutions (SPSS) 10 adalah sebagai berikut:

\begin{tabular}{|c|c|c|c|c|c|c|}
\hline Simbol & Variabel & $\begin{array}{l}\text { Koefisie } \\
\text { n Beta }\end{array}$ & $\begin{array}{l}\text { Nilai } \\
\text { koefisien }\end{array}$ & $\begin{array}{l}\text { Standard } \\
\text { Error }\end{array}$ & t-value & $p$ \\
\hline \multirow{5}{*}{$\begin{array}{l}P \\
\mathrm{KD} \\
\mathrm{KP}\end{array}$} & Konstanta & $a$ & 2.538 & .946 & 2.683 & .009 \\
\hline & Partisipasi & $\beta_{1}$ & 0.834 & .303 & 2.757 & .007 \\
\hline & Keadilan Distributif & $\beta_{2}$ & $-7.63 \mathrm{E}-02$ & .135 & -.563 & .575 \\
\hline & Keadilan & $\beta_{3}$ & & & & \\
\hline & Prosedural & & 0.592 & .155 & 3.825 & .000 \\
\hline KO & Goal commitment & $\beta_{4}$ & -.897 & .366 & -2.449 & .017 \\
\hline $\begin{array}{l}R= \\
0,503\end{array}$ & $\mathrm{R}^{2}=.253$ & $F=6,253$ & $p=.000$ & $N=79$ & & \\
\hline
\end{tabular}

Hasil analisis menunjukkan bahwa korelasi atau hubungan antara Kinerja dengan keempat variabel independennya kuat dijelaskan dengan angka $R=0,503$. Angka $R$ square atau koefisien determinasi adalah 0,253 yang berarti $25,3 \%$ variasi dari kinerja bisa dijelaskan oleh variasi keempat variabel independennya, dan sisanya $(100 \%-25,3 \%=74,7 \%)$ dijelaskan oleh sebabsebab lainnya. 
Berdasarkan pengujian ANOVA atau $\mathrm{F}$ test, didapat $\mathrm{F}$ hitung adalah 6,253 dengan tingkat signifikansi 0,000 . Karena probabilitasnya jauh lebih kecil dari 0,05 maka model regresi bisa dipakai untuk memprediksi Kinerja. Atau bisa dikatakan, Partisipasi, Keadilan Distributif, Keadilan Prosedural dan Goal commitment secara bersama-sama berpengaruh terhadap Kinerja.

Nilai koefisien regresi untuk Partisipasi adalah 0,834 dan tingkat signifikansi $p<0,05$. Hasil penelitian ini dengan demikian mendukung hipotesis (1), yang berarti partisipasi dalam penyusunan anggaran berpengaruh secara signifikan terhadap kinerja

Koefisien regresi untuk Keadilan Distributif adalah negatif dengan tingkat signifikansi $p>0,05$ berarti Persepsi Keadilan Distributif tidak berpengaruh terhadap kinerja. Hasil penelitian ini tidak mendukung hipotesis 2 yang berarti Keadilan Distributif tidak berpengaruh signifikan terhadap Kinerja.

Koefisien regresi persepsi Keadilan Prosedural menunjukkan nilai 0,592 dengan tingkat signifikansi $p<0,05$ berarti Keadilan Prosedural berpengaruh signifikan terhadap Kinerja. Koefisien regresi Goal commitment menunjukkan nilai $-0,897$ dengan tingkat signifikansi $p<0,05$. Koefisien yang negatif dan signifikan menunjukkan goal commitment yang tinggi menunjukkan kinerja yang rendah.

\section{SIMPULAN}

Penelitian ini menguji pengaruh partisipasi anggaran, keadilan distributif, keadilan prosedural dan goal commitment terhadap kinerja Dinas. Simpulan yang dapat dipaparkan dari hasil analisis dan pengujian hipotesis adalah Penelitian ini membuktikan partisipasi berpengaruh terhadap kinerja. Hasil yang positif dan signifikan menunjukkan partisipasi dalam penyusunan anggaran di Pemerintah Daerah Kabupaten Badung mempunyai pengaruh yang signifikan terhadap kinerja Dinas. Hasil ini mirip dengan yang dihasilkan oleh Kenis (1979), Brownell (1982), Brownell dan Mc.Innes (1986), Frucot dan Shearon (1991), dan Indriantoro (1995) yang menyatakan partisipasi penyusunan anggaran berpengaruh terhadap kinerja. Pengaruh Keadilan Distributif terhadap Kinerja Dinas menunjukkan hasil yang positif namun tidak signifikan yang artinya tidak mendukung hipotesis 2 bahwa keadilan distributif berpengaruh terhadap Kinerja. Hasil ini sesuai dengan pendapat Wentzel (2002) yang menyatakan persepsi keadilan distributif tidak memiliki pengaruh langsung terhadap kinerja. Hal ini menunjukkan persepsi keadilan distribusi anggaran di Pemda Badung masih sangat lemah. Seperti yang dinyatakan oleh Cropanzano (2000), persepsi keadilan yang rendah menunjukkan bahwa masih terdapat perlakuan tidak adil yang dirasakan terhadap distribusi anggaran. Persepsi Keadilan Prosedural menunjukkan ada pengaruh terhadap kinerja Dinas. Hal ini ditandai dengan hasil yang positif dan signifikan. Hasit pengujian ini nampaknya tidak dapat mendukung pendapat Wentzel (2002) dan Linquist (1995) yang menyatakan tidak ada pengaruh antara persepsi Keadilan Prosedural terhadap Kinerja, namun mendukung pendapat Libby (1999) yang menyatakan proses penganggaran yang adil membawa pengaruh yang positif terhadap kinerja. Hasil pengujian terhadap goal commitment dengan kinerja menunjukkan hasil yang negatif dan signifikan. Hal ini berarti pengaruh goal commitment terhadap kinerja menunjukkan arah hubungan yang tidak searah. Hasil penelitian yang negatif dan signifikan tidak dapat mendukung pendapat Wentzel (2002) serta Locke dan Latham (1990) yang menyatakan kinerja individu lebih baik ketika mereka menerima dan memiliki komitmen untuk mencapai tujuan khusus. Hal ini kemungkinan disebabkan karena persepsi tujuan anggaran di Dinas masih memakai paradigma yang lama, yaitu realisasi anggaran harus sesuai dengan penerimaan anggaran. Sehingga kecendrungannya adalah pada bagaimana menghabiskan anggaran pada akhir masa anggaran, sehingga meskipun komitmen terhadap sasaran tercapai, tetapi apabila pada akhir masa anggaran masih terdapat sisa anggaran, hal itu dapat dikatakan kinerja yang rendah.

Hasil penelitian ini memiliki beberapa keterbatasan dan hendaknya keterbatasan ini dapat lebih diperhatikan untuk penelitian-penelitian berikutnya. Keterbatasan tersebut adalah pengisian 
kuesioner dipengaruhi oleh subyektivitas responden dan beberapa diisi dengan mengikuti apa yang dibuat oleh atasan. Hal ini tentu akan mempengaruhi hasil pengujian hipotesis; responden penelitian ini hanya terbatas pada pimpinan Dinas Kabupaten Badung-Bali. Penelitian ini mungkin akan menunjukkan hasil yang berbeda jika diterapkan pada seluruh Dinas yang ada di Kota, Kabupaten dan Propinsi di Bali sehingga hasil penelitian ini tidak dapat digeneralisasi; dan alat ukur untuk mengukur kinerja hanyalah dari aspek kinerja anggaran sehingga belum mencakup aspek kinerja manajerial. Hal ini dapat menghasilkan hasil yang berbeda jika dipandang dari sisi pimpinan Dinas sebagai manajer.

Implikasi langsung dari temuan ini adalah usaha untuk mengefektifkan kinerja dalam anggaran partisipatif menjadi tidak mungkin manakala aspek keadilan distributif, keadilan prosedural dan goal commitment diabaikan. Namun hendaknya untuk meningkatkan validitas eksternal, bagi penelitian-penelitian berikutnya yang menguji masalah pengaruh partisipasi anggaran dengan kinerja hendaknya dapat memperluas baik dari cakupan wilayah populasi dan variabel yang akan diuji. Beberapa peneliti menyatakan implikasi kinerja dari partisipasi penyusunan anggaran yang bersifat partisipatif dipengaruhi oleh atribut psikologis seperti motivasi, locus of control dan sikap; faktor organisasional seperti tingkat desentralisasi dan gaya kepemimpinan, dan lingkungan seperti ketidakpastian dan volatility (Riyanto, 1999). Peneliti menyarankan untuk penelitian berikutnya selain mencoba menggunakan variabel-variabel tersebut sebagai variabel pemoderasi hubungan antara partisipasi anggaran dengan kinerja di Pemerintah daerah di Indonesia, selain itu juga dapat memasukkan beberapa dimensi struktur yang relevan yang menunjukkan hal-hal yang sangat terlibat dalam persepsi keadilan seperti konsentrasi kekuasaan, tingkat pendapat individu, kemampuan mempengaruhi yang lainnya, keberadaan aturan dan peraturan formal dan lain lain (Cropanzano, 2000). Rekomendasi bagi penelitian mendatang dapat diarahkan pada pengkajian yang lebih mendalam pada cakupan yang lebih luas atau pada unit pemerintah yang lain dengan menggunakan variabel outcome seperti kepuasan kerja, tekanan kerja, sikap terhadap anggaran selain kinerja.

\section{DAFTAR PUSTAKA}

Adams, J.S., (1965), "Inequity in Social Exchange", In Advances in Experimental Psychology, Vol.2, edited by L. Berkowitz: 267-299, New York.NY: Academic Press.

Adoe, H. Maryanti, (2002), Pengaruh Karakteristik Tujuan Anggaran terhadap Perilaku Sikap, dan Kinerja Aparat Pemerintah Daerah di Propinsi Nusa Tenggara Timur, Tesis S-2 UGM.

Anthony, Robert N. dan David W. Young, (1999), Management Control in Nonprofit Organizations, Sixth Edition. IRWIN.

Argyris, C., (1952), The Impact of Budget on People, Ithaca: School of Business and Public Administration, Cornel University.

Brownell, P., (1981), "Participation in Budgeting, Locus of Control and Organizational Effectiveness", The Accounting Review 56(4): 844-860.

Brownell, P., (1982), "A Field Study Examination of Budgetary Participation and Locus of Control", The Accounting Review, Vol. LVII No.4. October. 
Brownell, P. dan M. Mc. Innes, (1986), "Budgetary Participation, Motivation, and Managerial Performance”, The Accounting Review, 61 October: 587-600.

Bryan dan Locke, (1967), "Goal Setting as a Means of Increasing Motivation, and Managerial Performance", Journal of Applied Psychology, 52 June: 274-277.

Caiden, Naomi, (1989), "A New Perspective on Budgetary Reform", Australian Journal of Public Administration, Vol. 48 No.1. March.

Campo-S. Salvatore \& Daniel Tommasi, (1999), Managing Government Expenditure, Asian Development Bank, Manila-Phillipina.

Chenhall, R.H. dan P. Brownell, (1988), "The Effect of Participative Budgeting on Job Satisfaction and Performance: Role Ambiguity as an Intervening Variable", Accounting, Organization, and Society, 13 (No.3): 225-233.

Chia, Y.M., (1995), "Decentralization, Management Accounting System (MAS) Information Characteristics and Their Interaction Effects on Managerial Performance: A Singapore Study", Journal of Business Finance \& Accounting: 811-830.

Cohen, R.L., (1987), "Distributif Justice: Theory and Research", Social Justice Research, 1: 19-40.

Cowherd, D.M. dan Levine, D.I., (1992), "Product Quality and Pay Equity between Lower-Level Employees and Top Management: An Investigative of Distributive Justice Theory", Administrative Science Quarterly, 37: 302-320.

Cropanzano, Russel S., Schminke M. dan Maureen L. Ambrose, (2000), "The Effect of Organizational Structure on Perceptions of Prosedural Fairness", Journal Of Applied Psychology, Vol. 85, No. 2: 294-304.

Daly, J.P. dan Geyer, P.D., (1994), "Procedural Fairness and Organizational Commitment Under Conditions of Growth and Decline", Social Justice Research, 8: 137-151.

Daly, J.P. dan Morris Mclnnes, (1986), "Budgetary Participation, Motivation, and Managerial Performance", The Accounting Review, Vol. LXI, October.

Donald, Cooper R. dan C. William Emory, (1999), Business Research Method, Terjemahan Sitompul G.E dan Imam Nurmawan, PT. Gelora Aksara Pratama.

Douthitt, A. Elizabeth dan John R. Aiello, (2001), "The Role of Participation and Control in the Effects of Computer Monitoring on Fairness Perceptions, Task Satisfaction, and Performance", Journal of Applied Psychology, Vol 86, No.5: 867-874.

Early, P.C. dan E.A. Lind, (1987), "Procedural Justice and Participation in Task Selection: The Role of Control in Mediating Justice Judgments", Journal of Personality and Social Psycology, 56 (6): 1148-1160.

Erez, M., dan R. Arad, (1986), "Participative Goal Setting: Social, Motivational, and Cognitive Factors", Journal of Aplied Psychology, 71 (4): 591-597. 
Folger, R., (1977), "Distributif and Procedural Justice: Combined Impact of "Voice" and Improvement on Experienced Inequity", Journal of Personality and Social Psychology, 35: 108-119.

French, J.R.P., Kay, dan H.H. Meyer, (1996), "Participation and The Appraisal System", Human Relation, June: 3-19.

Frucot, Veronique dan Shearon Winston T., (1991), "Budgetary Participation, Locus of Control and Mexican Managerial Performance and Job Satisfaction", The Accouting Review, January: 80-89.

Ghozali, Imam, (2001), Aplikasi Analisis Multivariate dengan Program SPSS, Badan Penerbit Universitas Diponegoro.

Gilliland, S.W., (1993), "The Perceived Fairness of Selection Systems: An Organizational Justice Perspective", Academy of Management Review, 18 (4): 694-734.

Govindarajan, V., (1986), "Impact of Participation in The Budgetary Process on Managerial Attitudes and Performance: Universilistic and Contingency Perspectives", Decision Sciences, 17: 496-516.

Greenberg. J., (1993), "The Social Side of Fairness: Interpersonal and Informational Classes of Organizational Justice. In R. Cropanzano", Justice in The Workplace: Approaching Fairness in Human Resource Management, 79-103. Hillsdale, NJ: Lawrence Erlbaum Press.

Gul, FA dan Y.M. Chia, (1994), "The Effect of Management Accounting Systems, Perceived Enviromental Uncertainty and Decentralization on Managerial Performance: A Test of Three Way Interaction", Accounting, Organization and Society, Vol. 19 No. 4:413-426

Halim, Abdul, (2002), Bunga Rampai Manajemen Keuangan Daerah, UPP AMP YKPN.

Hair, J.F. Jr., R.E. Anderson, R.L. Tatham, dan W.C. Black, (1998), Multivariate Data Analysis, Fifth Edition. New Jearsey: Prentice Hall International. Inc.

Hansen, R.Don dan \& Mowen M. Maryanne, (2001), Cost Management: Accounting and Control, $2^{\text {nd }}$ ed., Terjemahan Thomson Learning. Penerbit PT. Salemba Empat. Jakarta.

Hariyanto, E. dan Pinasti M., (2002), "Pengaruh Keikutsertaan Manajer dalam Penyusunan Budget terhadap Perilaku Manager yang Kinerjanya Dinilai dengan Informasi Akuntansi", Simposium Nasional Akuntansi 5, Semarang.

Homans,G.C., (1961), Social Behavior: Its Elementary Forms, New York, NY: Harcourt, Brace, and World.

Hopwood, A.G., (1972), "An Empirical Study of The Role of Accounting Data in Performance Evaluation", Journal Accounting Research. Vol. X: 156-193.

Indriantoro, Nur, (1995), Accountancy Development in Indonesia; The Effect of participative Budgeting on Job Performance and Job Satisfaction with Locus of Control and Cultural 
Dimensions as Moderting Variables, Tim Koordinasi Pengembangan Akuntansi, LPFEUI, Jakarta.

Indriantoro, Nur dan Supomo B., (1999), Metodologi Penelitian Bisnis untuk Akuntansi dan Manajemen, Edisi pertama, BPFE-Yogyakarta.

Indriani, Mirna, (1993), Pengaruh Partisipasi Penyusunan Anggaran terhadap Prestasi Kerja dan Kepuasan Kerja pada Aparat Pemerintah Daerah Tingkat II Propinsi Daerah Istimewa Aceh, Tesis S-2 UGM.

Ishi, Hiromitsu, (1996), "Budgets and The Budgetary Process in Japan", Hitosubashi Journal of Economics, 37. 1-19

Jason, Colquitt A., Wesson J. Michael, Porter H.L.O., Conton E. Donald, dan Ng Yee K., (2001), "Justice at Millenium: A Meta-Analytic Review of 25 Years of Organizational Justice Research", Journal of Applied Psychology. Vol 86. No.3: 425-445.

Jones, Rowan, dan Maurice P., (1996), Public Sector Accounting, Fourth Edition, Pitman Publishing

Kenis, I., (1979), "Effects of Budgetary Goal Characteristics on Managerial Attides and Perfomance", The Accounting Review, 54 (4): 707-721.

Klein, J. Howard, Wesson J. Michael, Hollenbeck R. John, Wright M. Patrick dan DeShon P.Richard, (2001), "The Assesment of Goal commitment: A measurement Model MetaAnalysis", Organizational Behaviour and Human Decision Processes, Vol. 85, No.1. May: 32-55.

Kren, L., (1992), "Budgetary Participation and Managerial Performance: The Impact of Information and Environmental Volatility", The Accounting Review, July: 511-526.

Kreitner, R. dan Angelo Kinicki, (2000), Organizational Behavior, Irwin McGraw-Hill, Fifth edition.

Latham, G.P., dan T.P. Steele, (1983), "The Motivational Effects of Participation versus Goal Setting on Performance", Academy of Management, 26: 406-417.

Leventhal, G.S., (1980), What Should Be Done with Equity Theory? In Social Exchange:Advances in Theory and Research, edited by K.J. Gergen, M.S. Greenberg, and R.H. Willis: 27-55, New York, NY: Plenum Press.

Libby, T., (1999), "The Influence of Voice and Explanation on Performance in Participative Budgeting Setting", Accounting, Organizations, and Society, 24: 125-137.

Lind, E.A. and T. Tyler, (1988), The Social Psychology of Procedural Justice, New York, NY: Plenum Press.

Linquist, T.M., (1995), "Fairness as an Antecedent to Participative Budgeting: Examining the Effects of Distributve justice, Procedural Justice and Reference Cognitions on Satisfaction and Performance", Journal of Management Accounting Research, 7 (Fall): 122-147. 
Locke, E.A., Shaw K.N., Saari, L.M. dan Latham, G.P., (1981), "Goal Setting and Task Performance: 1969 - 1980”, Psychological Bulletin, 90: 125 - 152.

Locke, E.A., G.P. Latham, dan M. Erez, (1988), "The Determination of Goal Commitment", Academy of Management Review, 13 (1): 23-39.

Magner, N., dan R.B. Welker, (1994), "Responsibility Center Managers Reactions to Justice in Budgetary Resouce Allocation. Advances in Reactions to Justice in Budgetary Resouce Allocation", Advances in Management Accounting, 3: 237-253.

Magner, N. dan Gary G. Johnson, (1995), "Municipal Official's Reactions to Justice in Budgetary Resource", PAQ, Winter: 439-436.

Mardiasmo, (2001), "Budgetary Slack Resulted from the Effects of Local Government Financial Dependency on Central and Provincial Government in Planning and Preparing Local Government Budget. The Case of Indonesia", Jurnal Riset Akuntansi Manajemen, Ekonomi, Vol.1 No.1:33-54.

Mardiasmo, (2002a), Akuntansi Sektor Publik, Penerbit Andi. Yogyakarta.

Mardiasmo, (2002b), Otonomi \& Managemen Keuangan Daerah. Penerbit Andi. Yogyakarta.

Farlin, Mc. D. B., dan Sweeney P.D., (1992), "Distributif and Procedural Justice as Predictors of Satisfaction with Personal and Organizational Outcomes", Academy of Management Journal, 35: $626-637$.

Mia, L., (1988), "Managerial attitude, Motivation and The Effectiveness of Budget Participation", Accounting, Organization and Society, 13: 465-475.

Milani, K., (1975), "The Relationship of Participation in Budget-Setting to Industrial Supervisor Performance and Attitudes: A Field Study", The Accounting Review, 50 (2): 274-283.

Mpaata, A. Kaziba dan Hani Handoko, (1998), "Participation: A Challenge to Organizational Behavior Research", Jurnal Ekonomi dan Bisnis Indonesia, Vol.13, No.I: 53-63.

Murray, Dennis, (1990), "The Performance Effects of Participatice Budgeting: An Integration on Intervening \& Moderating Variables", Behavior Research in Accounting, Vol 2.

Nafi, M., (1998), Pengaruh Gaya Kepemimpinan, Strategi, dan Ketidakpastian Lingkungan terhadap Partisipasi Anggaran, Tesis S-2 UGM.

Panggabean, S. Mutiara, (2002), "Pengaruh Keadilan dalam Penggajian dan Perilaku Individu terhadap Kinerja Dosen pada Perguruan Tinggi Swasta", Kajian Bisnis, No. 26. MeiAgustus.

Pareke, Js. Fahrudin, (2000), Keadilan Distributif dan Keadilan Prosedural Sebagai Determinan Kepuasan pada Penilaian Kinerja dan Komitmen Organisasional, Tesis S-2 UGM. 
Pasoloran, Oktavianus, (2002), "Pengaruh Perceived Environment Uncertainty (PEU) terhadap Hubungan antara Karakteristik Sasaran Penganggaran dengan Kinerja Manajerial", Simposium Nasional Akuntansi, 5. Sesi 5 D.

Perda Kabupaten Badung No.2 tahun 2001: Organisasi dan Tata Kerja Perangkat Daerah dan Sekretariat Dewan Perwakilan Rakyat Daerah Kabupaten Badung.

Porter, L.W., R.M. Steers, R.T. Mowday, dan P.V. Boulian, (1974), "Organizational Commitment, Job Satisfaction, and Turn Over Among Psyatric Technicians", Journal of Applied Psychology , 59: 603-609.

Riyanto, B., (1999), "A Test of The Effect of Attitude, Strategy and Decentralization on Budget articipation: A System of Fit Approach" Jurnal Riset Akuntansi Indonesia, Vol.2 No.2: 136153.

Riyanto, B., (2001), "Alternative Approach to Examine A Contingency Model in Accounting Research: A Comparison", Jurnal Riset Akuntansi Manajemen, Ekonomi, Vol.1 No. 1. Februari 2001: 1-12.

Santoso, Singgih, (2000), Buku Latihan SPSS Statistik Parametrik, Elex Media Komputindo, Jakarta.

Shields, J.F., dan M.D. Shields, (1998), "Antecedent of Participative Budgeting", Accounting, Organization and Society, 23 (1): 49-76.

Siegel, G., dan Helena R. Marconi, (1989), Behavioral Accounting, South-Western Publishing Co. Cincinnati-Ohio.

SK. Menteri Dalam Negeri No.29/2002 tentang Pedoman Pengurusan, Pertanggungjawaban dan Pengawasan Keuangan Daerah serta Tata Cara Penyusunan Anggaran Pendapatan dan Belanja Daerah, Pelaksanaan Tata Usaha Keuangan Daerah dan Penyusunan Perhitungan Anggaran Pendapatan dan Belanja Daerah.

Sterdy, A.C., (1960), Budget, Control and Cost Behavior, Prentice Hall Inc. Englewood, Cliff. N.J.

Tang, Li-Ping, Thomas dan Linda J. Sarsfield Baldwin, (1996), "Distributive and Procedural Justice as Related to Satisfaction and Commitment, SAM Advanced Management Journal,.Summer: 25-31.

Tommasi, D. dan Salvatore Schiavo-Campo, (1999), Managing Government Expenditure, Asian Development Bank, Manila-Philippines.

Tyler, T.R., (1989), "The Psychology of Procedural Justice: A Test of The Group Value Model", Journal of Personality and Social Psychology, 57 (5): 830-838.

Vincent, Chong K. dan Chong Ming Kar, (2002), "Budget Goal Commitment and Informational Effects of Budget Participation on Performance: A Structural Equitation Modeling Approach", Behavioral Research in Accounting, Volume 14: 65-86. 
KINERJA, Volume 9, No.2, Th. 2005: Hal. 98-112

Wentzel, Kristin, (2002), "The Influence of Fairness Perceptions and Goal commitment on Managers Performance in A Budget Setting", Behavior Research in Accounting, 14: 247271.

Wildavsky, (1994), "Budgetary Control in A Decentralized System: Meeting the Criteria for Fiscal Stability in the European Union", Public Budgeting and Finance.

Wright, M. Patrick, Anne M. O'Leary-Kelly, Jose M. Cortina, Howard J.Klein, dan John R. Hollenbeck, (1994), "On the Meaning and Measurement of Goal Commitment", Journal of Applied Psychology, Vol 79. No. 6: 795-803. 